\title{
Discovery of a Novel, Potent, and Specific Family of Factor Xa Inhibitors via Combinatorial Chemistry
}

\author{
James A. Ostrem,* Fahad Al-Obeidi, Pavel Safar, Alena Safarova, Steven K. Stringer, Marcel Patek, \\ M. Todd Cross, James Spoonamore, Jeff C. LoCascio, Padmaja Kasireddy, David S. Thorpe, Nikolai Sepetov, \\ Michal Lebl, Peter Wildgoose, and Peter Strop \\ Selectide Corporation, a subsidiary of Hoechst Marion Roussel, 1580 East Hanley Boulevard, Tucson, Arizona 85737
}

Received May 16, 1997; Revised Manuscript Received November 6, 1997

\begin{abstract}
A series of low molecular weight peptide inhibitors of factor Xa, unrelated to any previously described, was identified by screening a combinatorial peptide library composed of L-amino acids. The minimal inhibitory sequence is a tripeptide, L-tyrosinyl-L-isoleucyl-L-arginyl, which competitively inhibits the hydrolysis of small chromogenic substrates by factor Xa but binds in an orientation which prevents a productive nucleophilic attack by serine 195 of the catalytic triad on the carbonyl carbon of the carboxyterminal arginine. The initial leads identified in an octamer combinatorial peptide library ranged in potency from 4 to $15 \mu \mathrm{M}$. These peptides were modified into peptide mimetics with a greater than 1000 -fold increase in potency while retaining unusual selectivity for factor Xa over the related serine proteases thrombin, factor VIIa/tissue factor, plasmin, activated protein C, kallikrein, and trypsin. One of the most potent analogues, SEL 2711, with a $K_{\mathrm{i}}$ of $0.003 \mu \mathrm{M}$ for factor $\mathrm{Xa}$ and $40 \mu \mathrm{M}$ for thrombin, is active in in vitro and ex vivo coagulation assays, suggesting the potential application of these inhibitors in anticoagulant therapy.
\end{abstract}

Hemostasis limits blood loss by the complex interaction of two interdependent processes. The primary hemostatic mechanism, platelet activation and formation of a platelet plug, typically occurs within seconds at a site of injury. A second, slower process, activation of the coagulation cascade, produces fibrin which, together with adherent platelets, forms a stable hemostatic clot (I). Both components of hemostasis rely on the selective activation of a series of latent and closely related serine proteases in the plasma. Historically, two pathways leading to the activation of thrombin, the final protease in the coagulation cascade, have been described (2, 3 ). Both pathways converge at the step where the proenzyme factor $\mathrm{X}$ is activated by proteolytic cleavage to factor $\mathrm{Xa}$. Once assembled in the prothrombinase complex with factor $\mathrm{Va}$ and calcium ions on a phospholipid surface, factor Xa converts prothrombin to thrombin, again by proteolytic cleavage. Thrombin acts at several sites, activating factors $\mathrm{V}$ and VIII (both of which amplify factor Xa production), cleaving fibrinogen to form fibrin, and activating platelets by cleaving the extracellular portion of the platelet thrombin receptor.

The central role of thrombin in forming both platelet and fibrin-rich thrombi has prompted the development of thrombinspecific inhibitors as anticoagulants with the assumption that a safe and effective level of anticoagulation can be achieved without excessive bleeding. Results from clinical trials with hirudin, a highly specific thrombin inhibitor, have shown that the therapeutic window for thrombin inhibitors may be narrower than expected $(4-6)$. Furthermore, thrombin

* To whom correspondence should be addressed, 520-544-5846 (voice mail), 520-575-8283 (fax), jim.ostrem@hmrag.com (e-mail). inhibitors will not by themselves prevent the continuing conversion of prothrombin, the most abundant of the vitamin K-dependent clotting proteins in the blood stream, to thrombin as long as the activity of factor $\mathrm{Xa}$ in the prothrombinase complex is uninhibited. Profound and specific inhibition of the prothrombinase complex, on the other hand, should eliminate the continued production of thrombin by either extrinsic or intrinsic pathways without interfering with a basal level of thrombin activity necessary for primary hemostasis. In support of this hypothesis, tick anticoagulant peptide (TAP), a 60 amino acid peptide with an inhibition constant $\left(K_{\mathrm{i}}\right)$ of $180 \mathrm{pM}$ for factor $\mathrm{Xa}$ in in vitro chromogenic assays $(7,8)$, is fully antithrombotic at doses which give modest increases in ex vivo coagulation assays and template and surgical bleeding times in animal models of venous thrombosis. TAP is also effective in models of arterial thrombosis in which heparin has little effect $(9-11)$. Other studies have shown that antagonists of thrombin production such as activated protein $\mathrm{C}$, inactivated factor VIIa, and factor Xa-specific inhibitors minimize the risk of hemorrhage at doses that produce an antithrombotic effect $(12-15)$.

We reasoned that peptide libraries should contain structures that are capable of interacting with the extended substrate binding region present in the factor Xa's active site pocket. Screening an octamer L-amino acid library with biotinylated human factor Xa conjugated with streptavidin alkaline phosphatase produced several beads that stained reproducibly, but that did not stain when factor Xa was inactivated with small active site inhibitors. We report here on the initial discovery and characterization of this unique family of peptide inhibitors for factor Xa. 


\section{EXPERIMENTAL PROCEDURES}

Library Screening. Peptide libraries were constructed using standard solid-phase peptide chemistry with FMOC ${ }^{1}$ protected amino acids on Tentagel $\mathrm{S} \mathrm{NH}_{2}$ resins (90 and 130 $\mu \mathrm{m})$ using split-synthesis methodology $(16-18)$. Human factor Xa (Enzyme Research Laboratories, Inc., South Bend, IN) was biotinylated with NHS-LC-biotin (Pierce, Rockford, IL) according to the manufacturer's directions. The biotinylated protein was desalted on G-25 in $20 \mathrm{mM}$ Tris-Cl, pH $7.8,100 \mathrm{mM} \mathrm{NaCl}$, and $0.01 \% \mathrm{NaN}_{3}$. Calcium chloride was added to a final concentration of $5 \mathrm{mM}$. Protein concentration was determined by Bradford (19) or BCA assay (Pierce, Rockford, IL). The biotinylated protein was diluted $50 \%$ (v/v) with glycerol and stored at $-20{ }^{\circ} \mathrm{C}$ until use. Biotinylated factor Xa was mixed with streptavidin-alkaline phosphatase (SAP, Pierce, Rockford, IL) and incubated at room temperature for $20 \mathrm{~min}$ prior to incubation with library beads. Aliquots of beads $\left[\left(0.5-1 \times 10^{6}\right)\right]$ were washed three times with HSBB-T (50 mM Tris-Cl, pH 7.8, $800 \mathrm{mM} \mathrm{NaCl}$, $0.05 \%$ PEG-8000, $0.1 \mathrm{mg} / \mathrm{mL}$ BSA, $0.25 \%$ Tween-20, and $0.01 \% \mathrm{NaN}_{3}$ ), then washed and incubated with QHSBB-TG (1/4X HSBB-T, $0.05 \% \mathrm{w} / \mathrm{v}$ gelatin) for $15 \mathrm{~min}$ at room temperature. The biotinylated factor Xa-SAP mixture was added to library beads (5-50 $\mathrm{nM}$ final concentration) in QHSBB-TG and incubated for $1 \mathrm{~h}$ with gentle mixing on a Nutator (Becton Dickinson, Sparks, MD). The beads were washed three times with QHSBB-T, three times with BCIP-T (250 mM Tris-Cl, $\mathrm{pH} 8.4,250 \mathrm{mM} \mathrm{NaCl}, 6 \mathrm{mM} \mathrm{MgCl} 2$, and $0.5 \%$ Tween-20), and incubated with substrate solution (BCIP, $0.165 \mathrm{mg} / \mathrm{mL}$ in BCIP-T) until color developed on individual beads, typically within 30-60 min. Beads with uniform blue color were picked from the library, stripped of protein by incubating in $8 \mathrm{M}$ guanidine- $\mathrm{HCl}$ for $15 \mathrm{~min}$, rinsed twice with deionized water, and destained in DMF. The destained beads were rinsed three times with HSBB-T and blocked in QHSBB-TG. Another aliquot of biotinylated factor Xa was mixed with SAP and inactivated by incubation with active site inhibitors Tenstop (tosyl-glycyl-3-amidinophenylalanine methylester, American Diagnostica Inc., Greenwich, CT) or PPACK (D-phenylalanyl-L-prolyl-Larginine chloromethyl ketone, Chemica Alta Ltd., Edmonton, Alberta) added to a final concentration of $50 \mu \mathrm{M}$ or $1 \mu \mathrm{M}$, respectively. The destained beads were incubated with the factor Xa-SAP-inhibitor mixture for $1 \mathrm{~h}$ at RT. Beads were washed and developed with BCIP substrate as described above. Beads picked from the library which showed no staining when incubated with active-site inhibited factor Xa under these conditions were briefly stripped and destained, then incubated with uninhibited factor Xa and SAP. Beads which restained were submitted for sequencing by Edman degradation. Peptides were resynthesized based on sequences obtained from individual beads. The purity of resynthesized peptides was $>90 \%$ based on absorbance at $215 \mathrm{~nm}$ in HPLC chromatograms. Peptide structures were verified by electrospray mass spectroscopy (Perkin-Elmers SCIEX) and amino acid analysis.

\footnotetext{
${ }^{1}$ Abbreviations: APTT, activated partial thromboplastin time; BCIP, 5-bromo-4-chloro-3-indolyl phosphate; DMSO, dimethyl sulfoxide; dPT, dilute prothrombin time; FMOC, fluorenylmethoxycarbonyl; pNA, p-nitroaniline; PPACK, D-phenylalanyl-L-prolyl-L-arginine chloromethyl ketone; SAP, streptavidin-alkaline phosphatase; Tenstop, tosyl-glycyl3 -amidinophenylalanine methylester; DMF, $N, N$-dimethylformamide.
}

Factor Xa Assay. Peptide stock solutions $(10 \mathrm{mM}$ in DMSO) were used to make serial 2-fold dilutions of peptide in $10 \%(\mathrm{v} / \mathrm{v})$ DMSO in TBS-PEG $(100 \mathrm{mM} \mathrm{NaCl}, 50 \mathrm{mM}$ Tris-Cl, pH 7.8, 0.05\% PEG-8000, and $0.01 \% \mathrm{NaN}_{3}$ ) for a final concentration of $4 \%$ DMSO in the assay. Kinetic assays were conducted at $25^{\circ} \mathrm{C}$ in half-area microtiter plates (Costar Corp., Cambridge, MA) using a kinetic plate reader (BioTek Instruments Inc., Winooski, VT). A typical assay consisted of $25 \mu \mathrm{L}$ of $2 \mathrm{nM}$ human factor $\mathrm{Xa}(0.5 \mathrm{nM}$ final concentration) combined with $40 \mu \mathrm{L}$ of inhibitor dilutions in $10 \% \mathrm{DMSO} / \mathrm{TBS}-\mathrm{PEG}$ and preincubated for $15 \mathrm{~min}$ at room temperature. The assay was initiated by the addition of $35 \mu \mathrm{L}$ of $500 \mu \mathrm{M} \mathrm{S}-2765$ [175 $\mu \mathrm{M}$ final concentration, Cbz-D-Arg-Gly-L-Arg-pNA, Pharmacia Hepar Inc., Franklin, $\mathrm{OH}]$. Inhibition constants were calculated from the slope of the progress curves during the linear part of the time course, typically between 1 and 5 min following addition of substrate to the assay.

Specificity Assays. Peptides were assayed for activity against purified proteases as described above. Human thrombin (1 nM final concentration, Enzyme Research Laboratories, South Bend, IN) was assayed in $400 \mu \mathrm{M}$ S-2366 (pyroGlu-Pro-Arg-pNA, Pharmacia Hepar Inc., Franklin, $\mathrm{OH})$. Human plasmin (10 nM, Pharmacia Hepar Inc., Franklin, OH) was assayed in $1.05 \mathrm{mM} \mathrm{S}-2251$ (D-Val-LeuLys-pNA, Pharmacia Hepar Inc., Franklin, OH). Human Protein $\mathrm{C}$ was activated with ACC enzyme (both gifts from W. Kisiel, University of New Mexico, Albuquerque, NM) according to Kisiel et al. (20). Activated protein C (27 nM) was assayed in $700 \mu \mathrm{M} \mathrm{S}-2366$. Human Factor VIIa (10 $\mathrm{nM}$ ) in the presence of $20 \mathrm{nM}$ tissue factor (TF, both gifts from W. Kisiel, University of New Mexico, Albuquerque, $\mathrm{NM}$ ) and $5 \mathrm{mM} \mathrm{CaCl}_{2}$ was assayed in $500 \mu \mathrm{M} \mathrm{S}-2288$ (DIle-Pro-Arg-pNA, Pharmacia Hepar Inc., Franklin, OH). Human plasma kallikrein $(2 \mathrm{nM}$, Athens Research and Technology, Athens, GA) was assayed in $250 \mu \mathrm{M} \mathrm{S}-2266$ (D-Val-Leu-Arg-pNA, Pharmacia Hepar Inc., Franklin, OH). Human trypsin $(0.5 \mathrm{nM}$, Athens Research and Technology, Athens, GA) was assayed in $250 \mu \mathrm{M} \mathrm{S}-2765$. tPA, human single chain tissue plasminogen activator $(5 \mathrm{nM}$ American Diagnostica, Inc., Greenwich, CT) was assayed in $2 \mathrm{mM}$ S-2765 at $37^{\circ} \mathrm{C}$.

Prothrombinase Assay. Measurement of factor Xa activity in the prothrombinase complex was conducted with several modifications to the assay described by Chattopadhyay et al. (21). The prothrombinase complex was prepared in a polypropylene tube by combining $2200-\mu \mathrm{L}$ of rabbit brain cephalin (RBC, Sigma) diluted 10-fold with physiological saline $(0.85 \% \mathrm{w} / \mathrm{v} \mathrm{NaCl}), 36 \mu \mathrm{L}$ of $1.6 \mu \mathrm{M}$ human $\mathrm{V} / \mathrm{Va}$ (ERL \#210, 80\% Va/20\% V, Enzyme Research Laboratories, South Bend, IN), $60 \mu \mathrm{L}$ of $30 \mathrm{nM}$ human factor Xa (Enzyme Research Laboratories, South Bend, IN), $2400 \mu \mathrm{L}$ of 0.71 mM S-2366 (Pharmacia Hepar Inc., Franklin, OH) and 600 $\mu \mathrm{L}$ of $100 \mathrm{mM} \mathrm{CaCl}_{2}$. Peptide dilutions were prepared by serial dilution in $10 \%$ DMSO/assay buffer $(50 \mathrm{mM}$ Tris-Cl, $\mathrm{pH} 7.8,200 \mathrm{mM} \mathrm{NaCl}, 5 \mathrm{mM} \mathrm{CaCl} 2,0.05 \%$ PEG-8000, and $\left.0.01 \% \mathrm{NaN}_{3}\right)$. Peptide dilutions $(40 \mu \mathrm{L})$ and the prothrombinase complex mixture $(50 \mu \mathrm{L})$ were combined in wells in a Costar half-area plate coated with Plastek A (MatTek Corp., Ashland, ME). The assay was initiated by addition of 10 $\mu \mathrm{L}$ of $6.8 \mu \mathrm{M}$ human prothrombin (Enzyme Research Laboratories, South Bend, IN). Absorbance at $405 \mathrm{~nm}$ was 
determined at 2 minute intervals for $30 \mathrm{~min}$ at $25^{\circ} \mathrm{C}$ in a kinetic plate reader (BioTek Instruments Inc., Winooski, VT). Slopes were determined from the linear portion of the time course, typically between 20 and $30 \mathrm{~min}$ after initiation of the assay. The octapeptides used in this assay (YIRLAAFT, YIREFSDY, and FIRLYVWN) showed less than $10 \%$ inhibition of thrombin activity at the highest concentration used in the prothrombinase assay (not shown).

Coagulation Assays. The ability of the peptides to prolong coagulation in platelet-poor plasma was assessed using in vitro and ex vivo coagulation assays. All research involving animals was conducted under a previously IACUC-approved protocol utilizing standard operating procedures in place at the time of the study. Animals were anesthetized with an intramuscular injection of xylazine $\mathrm{HCl}$ followed in 5 min with an intramuscular injection of ketamine $\mathrm{HCl}$. Blood samples collected in $3.8 \%$ sodium citrate solution at a ratio of 1 part sodium citrate to 9 parts whole blood. The blood was immediately centrifuged at $3500 \mathrm{~g}$ for $10 \mathrm{~min}$. Platelet poor plasma was removed and frozen at $-80^{\circ} \mathrm{C}$ until assay. Clotting times in the APTT and dilute prothrombin time (dPT) assays were determined with the ACL 3000 plus automated coagulation instrument (Instrumentation Laboratories, Milan, Italy) using IL brand thromboplastin for dPT times and Baxter Actin FS reagent for APTT times. In the dPT assay, thromboplastin is diluted until a clotting time of approximately $30 \mathrm{~s}$ is achieved. This is taken as $100 \%$ activity. Using research mode on the ACL instrument, a standard curve for calibration is established by serial 2-fold dilution of the diluted thromboplastin reagent. During the assay $50 \mu \mathrm{L}$ of sample ( $45 \mu \mathrm{L}$ plasma $+5 \mu \mathrm{L}$ inhibitor) is mixed with $100 \mu \mathrm{L}$ of thromboplastin reagent diluted to give an (uninhibited) clotting time of approximately $30 \mathrm{~s}$. Percent inhibition by compound in the plasma is determined by comparison of clotting times to the calibration curve constructed with the thromboplastin dilutions. Stability of the inhibitors in plasma and whole blood was determined by incubating peptide at a concentration that produced $60-$ $70 \%$ inhibition of coagulation in the dilute PT assay for 0 , 10, 20, 40, and $60 \mathrm{~min}$ at $37^{\circ} \mathrm{C}$ and initiating the dilute PT assay with thromboplastin/ $\mathrm{CaCl}_{2}$.

\section{RESULTS}

The amino acid sequences on individual beads identified by the screening assay and deduced by Edman degradation showed a remarkable conservation of a three amino acid sequence, Tyrosine-Isoleucine-Arginine, located primarily at the N-terminus of the peptide but in some cases preceded by a glycine residue at an internal position in the peptide sequence (Table 1). All resynthesized peptides containing the Tyr-Ile-Arg or Phe-Ile-Arg tripeptide motif inhibited factor Xa activity in chromogenic assays, with $K_{\mathrm{i}}$ values ranging from 4 to $15 \mu \mathrm{M}$. Furthermore, all peptides containing Tyr-Ile-Arg or Phe-Ile-Arg inhibited the conversion of prothrombin to thrombin in a defined assay of prothrombinase complex activity consisting of prothrombin, factor $\mathrm{Va}$, factor $\mathrm{Xa}$, phospholipid, and calcium ions (Figure 1). The IC50 values for the Tyr-Ile-Arg octapeptides in this assay (YIRLAAFT, $20 \mu \mathrm{M}$; YIREFSDY, $37 \mu \mathrm{M}$ ) compared favorably with the control compound Tenstop $(18 \mu \mathrm{M})$. The lower activity of FIRLYVWN (IC50 = $129 \mu \mathrm{M})$ in the prothrombinase assay was consistent with the observation

\begin{tabular}{|c|c|c|c|}
\hline bead & & & sequence \\
\hline TC6-1 & $\mathrm{Y}$ & I & R L A A F T \\
\hline TC6-6 & $\mathrm{Y}$ & I & R L T K M W \\
\hline TC6-22 & $\mathrm{Y}$ & I & $R \quad P \quad P L L$ \\
\hline TC6-24 & $\mathrm{Y}$ & I & $R L M E M T$ \\
\hline Tс6-16 & $\mathrm{Y}$ & I & $\mathrm{R} \mathrm{L} \mathrm{K} \mathrm{K} \mathrm{V} \mathrm{H}$ \\
\hline TC6-5 & $\mathrm{Y}$ & I & $R \quad V A Q L Y$ \\
\hline TC6-4 & $\mathrm{Y}$ & $I$ & $\mathrm{R} V \mathrm{M} N \mathrm{~N} R$ \\
\hline TC6-2 & $\mathrm{Y}$ & $I$ & $R$ I Y E R E \\
\hline TC5-2 & $\mathrm{Y}$ & $I$ & $R \quad Y \quad R \quad N \quad P \quad I$ \\
\hline TC6-3 & $\mathrm{Y}$ & $I$ & $R E F S D Y$ \\
\hline TC5-1 & $\mathrm{F}$ & $I$ & $R \quad L \quad Y \quad W N$ \\
\hline TC6-23 & $F$ & $I$ & $\mathrm{R} \quad \mathrm{L} P \mathrm{P} \quad \mathrm{Y} \mathrm{G}$ \\
\hline TC6-9 & $\mathrm{T}$ & $\mathrm{F}$ & $\underline{G} Y I R \quad K A$ \\
\hline TC6-21 & $\mathrm{N}$ & $\underline{\mathrm{G}}$ & $Y$ I R L I H \\
\hline
\end{tabular}

${ }^{a}$ The glycine residue preceding tyrosine in TC6-9 and TC6-21 is underlined to emphasize its occurrence before the Tyr-Ile-Arg consensus sequence. Assay conditions are described under Experimental Procedures.

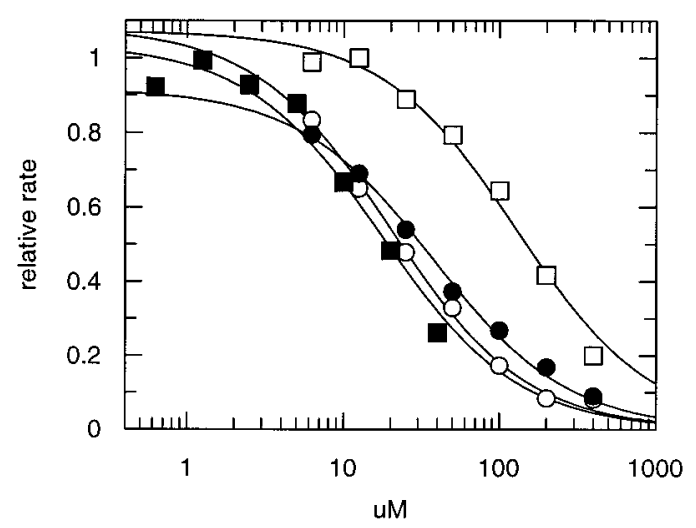

FIGURE 1: Inhibition of factor Xa activity in the prothrombinase complex. YIRLAAFT (O), YIREFSDY (@), FIRLYVWN ( $\square)$, and Tenstop (ם), were prepared in serial dilutions and assayed in a prothrombinase assay consisting of phospholipid (rabbit brain cephalin), $6 \mathrm{mM} \mathrm{Ca}^{2+}, 5 \mathrm{nM}$ V/Va (human), $170 \mathrm{pM}$ human factor $\mathrm{Xa}, 680 \mathrm{nM}$ human prothrombin, and $160 \mu \mathrm{M} \mathrm{S}-2366$ (pyro-GluPro-Arg-pNA). Means of duplicates are shown.

that peptides containing an N-terminal L-phenylalanine showed less inhibition of factor $\mathrm{Xa}$ than those containing $\mathrm{N}$-terminal L-tyrosine in the standard Xa chromogenic assay (not shown). A series of deletions of one of the peptides, TC6-1 (Tyr-Ile-Arg-Leu-Ala-Ala-Phe-Thr), showed that removing three to four residues from the $\mathrm{C}$-terminus had little effect on factor $\mathrm{Xa}$ inhibition in chromogenic assays, however, further truncations significantly reduced the observed $K_{\mathrm{i}}$ (Table 2). Peptides synthesized with a D-amino acid scan indicated that the stereochemistry of all five amino acid residues in the pentamer had a substantial effect on activity toward factor $\mathrm{Xa}$ (not shown). In most cases a significant reduction in inhibition was observed, the exception being a 10-20-fold enhancement of inhibition when the N-terminal L-tyrosine was replaced by D-tyrosine, an effect similar to that described for tripeptide aldehyde inhibitors for thrombin such as D-Phe-Pro-Arg-H $(22,23)$. Removing tyrosine from the N-terminus completely abolished inhibitory activity, as did replacing isoleucine with glycine or alanine, or replacing arginine with lysine or other amino-alkyl side chains (Table 2). 
Table 2: Truncations, Deletions, and Amino Acid Replacements

\begin{tabular}{lc}
\hline structure & $K_{\mathrm{i}}(\mu \mathrm{M})$ \\
\hline YIRLAAFT & 5 \\
YIRLA & 11 \\
YIR & 38 \\
YIR-OH & 63 \\
Ac-YIR & 3.8 \\
YIR & 1.4 \\
IRLA & $>200$ \\
YGRLA & $>200$ \\
YIKLA & $>200$ \\
\hline
\end{tabular}

${ }^{a}$ All peptides are $\mathrm{C}$-terminal amides with the exception of YIR-OH (C-terminal carboxylic acid). yIR, D-Tyr-Ile-Arg; Ac-YIR, $N$-acetylTyr-Ile-Arg.

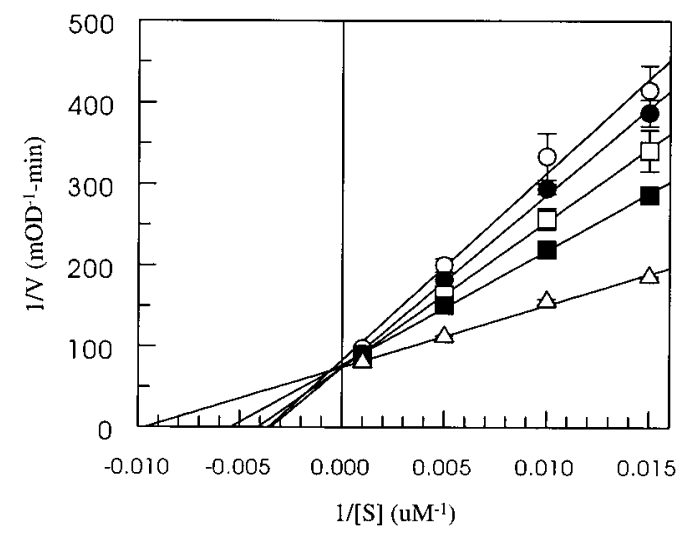

FIGURE 2: Competitive inhibition of substrate hydrolysis by TyrIle-Arg-Leu-Ala. Factor Xa activity was assayed with the chromogenic substrate Cbz-D-Arg-Gly-L-Arg-pNA (S-2765) by monitoring the increase in absorbance at $405 \mathrm{~nm}$ in kinetic assays, as described under Experimental Procedures. Tyr-Ile-Arg-Leu-Ala peptide was diluted in $10 \%$ DMSO/TBS-PEG, $\mathrm{pH} 7.8$, to produce final concentrations of $0(\triangle), 10(\square), 20(\square), 30(\bullet)$, and $40(O)$ $\mu \mathrm{M}$ inhibitor. Peptide and factor Xa (final concentration $0.5 \mathrm{nM}$ ) were preincubated at room temperature for $10 \mathrm{~min}$ prior to initiating the assays with substrate. All assays were conducted in duplicate.

As demonstrated in Figure 2, peptides containing the sequence Tyr-Ile-Arg showed competitive inhibition with the chromogenic substrate S-2765, implying that the consensus sequence interacts with the substrate binding pocket in factor Xa's active site. To determine whether the tripeptide binds in a substrate-like mode which might be converted into a more potent mechanism-based inhibitor, C-terminal $p$ nitroanilide (pNA) substrates of Tyr-Ile-Arg were synthesized and compared for hydrolysis by factor Xa, thrombin, and trypsin. Neither D-Tyr-Ile-Arg-pNA, or Ac-Tyr-Ile-Arg-pNA were cleaved by factor Xa (Figure 3). D-Tyr-Ile-Arg-pNA was readily cleaved by thrombin; however, Ac-Tyr-Ile-ArgpNA was a poor substrate requiring incubation with thrombin at $37{ }^{\circ} \mathrm{C}$ for $6 \mathrm{~h}$ to achieve partial hydrolysis. Both $p$-nitroanilide substrates were cleaved by trypsin. In contrast, both factor Xa and trypsin rapidly hydrolyzed the tripeptide Cbz-D-Arg-Gly-Arg-pNA (S-2765), while thrombin showed low activity toward this substrate. Further evidence that the tripeptide occupies the active site with the C-terminal carbonyl oriented in an unproductive position relative to the nucleophile serine 195 in factor Xa was obtained with the boronic acid derivative of Ac-Tyr-Ile-Arg. Figure 4 shows that this peptide potently inhibited trypsin $\left(K_{\mathrm{i}}=0.5 \mathrm{nM}\right)$ and thrombin $\left(K_{\mathrm{i}}=8.2 \mathrm{nM}\right)$, but was a low micromolar
A

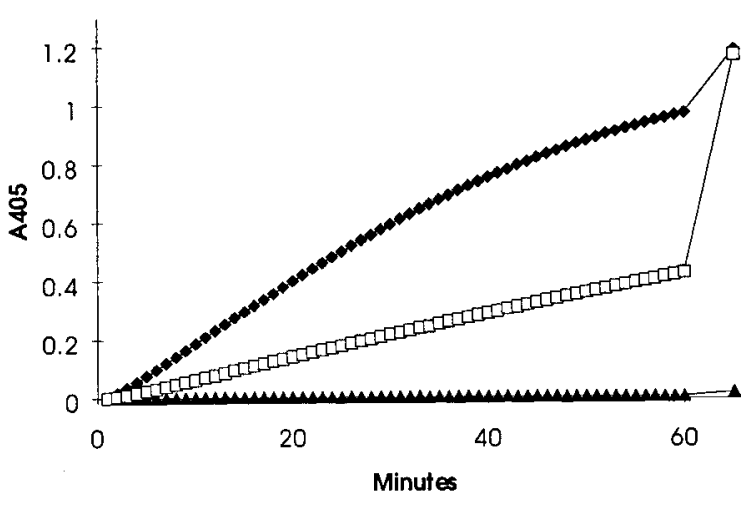

B

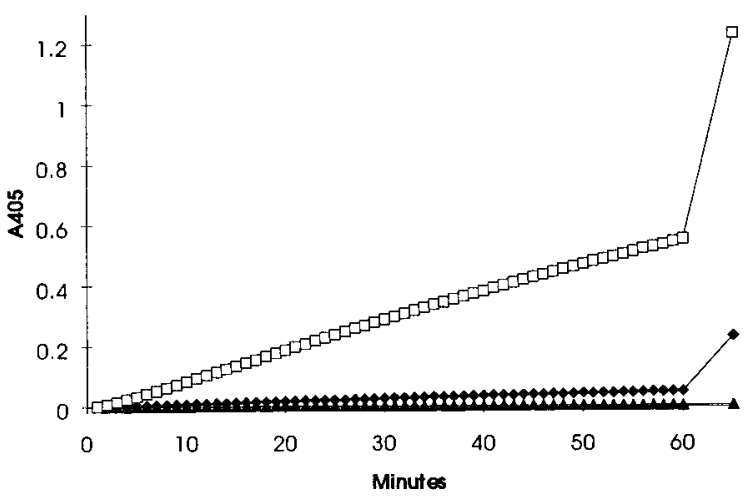

C

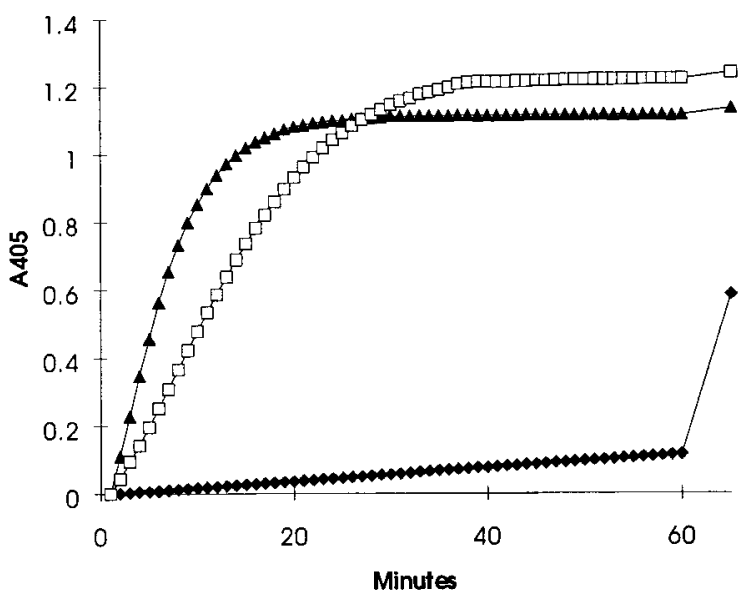

FIGURE 3: $p$-Nitroanilide substrate hydrolysis by factor $\mathrm{Xa}$, thrombin, and trypsin. (A) D-Tyr-Ile-Arg-pNA, (B) Ac-Tyr-Ile-ArgpNA, and (C) Cbz-D-Arg-Gly-L-Arg-pNA substrates were incubated at a final concentration of $200 \mu \mathrm{M}$ with $2 \mathrm{nM}$ factor Xa (ム), thrombin $(\diamond)$, or trypsin $(\square)$. Release of $p$-nitroaniline was monitored at $405 \mathrm{~nm}$ (y-axis) at $1 \mathrm{~min}$ intervals in a Biotek Instruments kinetic platereader at $37{ }^{\circ} \mathrm{C}$ for $60 \mathrm{~min}$. The plates were covered to prevent evaporation and incubated on a heating block at $37^{\circ} \mathrm{C}$ before taking a final reading at $360 \mathrm{~min}$.

inhibitor of factor Xa, consistent with the inhibition constant of the unmodified tripeptide amide (Table 2).

Other peptide derivatives mimicking the expected tetrahedral transition state intermediate (e.g., ketomethylene isosteres of the Arg-Leu bond) were tested with similar results (not shown). Structure-activity studies performed 
Table 3: Specificity of Factor Xa Inhibitors in in Vitro Chromogenic Assays ${ }^{a}$

\begin{tabular}{lllccccccc}
\hline SEL & \multicolumn{1}{c}{ structure } & Xa & thrombin & VIIa/TF & $K_{\mathrm{i}}(\mu \mathrm{M})$ plasmin & protein C & tPA & kallikrein & trypsin \\
\hline 1915 & YIRLPGLL & 4.0 & $\gg 200$ & $\gg 200$ & $>200$ & NA & $\gg 200$ & NA & $\gg 200$ \\
2219 & Ac( ${ }^{(}$Bu)-YIRLP & 0.055 & 54 & $\gg 200$ & $>200$ & NA & 38 & NA & $\gg 200$ \\
2489 & Ac-Phe(pNH2)-Chg-RLP & 0.025 & $\gg 200$ & $\gg 200$ & $>200$ & $\gg 200$ & $\gg 200$ & $\gg 200$ & $\gg 200$ \\
2711 & Ac-pAph-Chg-Pal3(Me)-LP & 0.003 & 40 & $>200$ & 130 & 10 & 0.12 & NA & 112 \\
\hline
\end{tabular}

${ }^{a}$ All peptides are $\mathrm{C}$-terminal amides. The one-letter amino acid code is used for naturally occurring amino acids, $\mathrm{Ac}$ is $N$-acetyl, $\mathrm{Ac}\left({ }^{\mathrm{i}} \mathrm{Bu}\right)-\mathrm{Y}$ is $\mathrm{N}$-acetyl, $\mathrm{N}$-isobutyl L-tyrosine, Phe(pNH2) is L-4-aminophenylalanine, Chg is L-cyclohexylglycine, pAph is L-4-amidinophenylalanine, Pal3(Me) is L-3-pyridyl(3-methyl)alanine. NA, not assayed; $\gg$, less than 10\% inhibition of activity observed at this concentration of inhibitor; >, less than 50\% inhibition observed at this concentration of inhibitor.

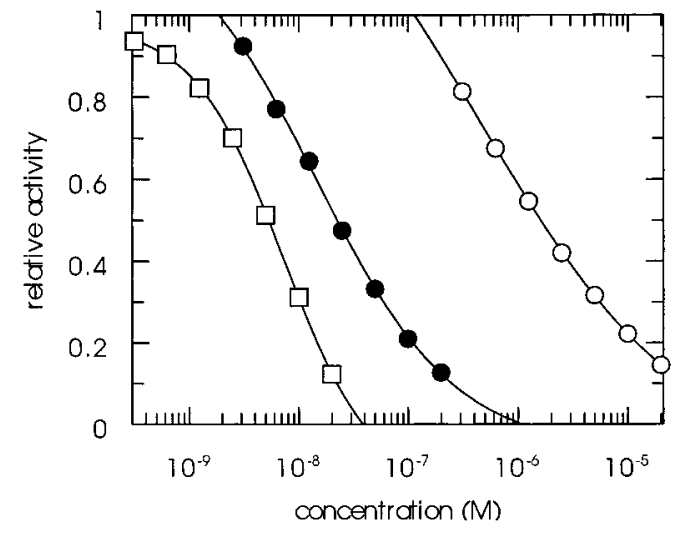

FIGURE 4: Inhibition curves for Ac-Tyr-Ile-Arg-B $(\mathrm{OH})_{2}$ tripeptide incubated with $0.5 \mathrm{nM}$ factor $\mathrm{Xa}(\mathrm{O}), 1 \mathrm{nM}$ thrombin $(\mathbf{O})$, or $2 \mathrm{nM}$ bovine trypsin $(\square)$. The synthesis of the boronic acid tripeptide followed the procedure described by Kettner et al. (33). Serial 2-fold dilutions of the peptide stock solution were assayed as described under Experimental Procedures.

by synthesizing individual peptide analogues led to compounds with simple chemical modifications of the N-terminal amino group which were orders of magnitude more potent without significantly affecting specificity for factor Xa (Table 3). However, although potent in chromogenic activity assays and in vitro coagulation assays, initial experimental work looking at half-life in rats following i.v. bolus injections showed that $\mathrm{N}$-acyl, $\mathrm{N}$-alkyl peptides were inactivated or cleared from plasma within 1-2 min. A series of potent inhibitors with greater half-life in vivo were generated by a combination of dedicated secondary libraries based on the Tyr-Ile-Arg motif and rational design. Substitution of cyclohexylglycine for isoleucine and introduction of a positive charge at the $\mathrm{N}$-terminus of the peptide with p-aminophenylalanine resulted in the pentapeptide Ac-Phe(pNH2)-Chg-Arg-Leu-Pro (SEL 2489), with a $K_{\mathrm{i}}$ of $25 \mathrm{nM}$ in chromogenic assays. In in vitro coagulation assays SEL 2489 inhibited thromboplastin-induced coagulation in the dilute PT assay with an IC50 of $0.9 \mu \mathrm{M}$ (Figure 5A). In addition to being a highly specific inhibitor of factor Xa (Table 3), SEL 2489 showed dose-dependent anticoagulant activity following i.v. injection in rats (not shown) and rabbits (Figure 5B). To determine whether the rapid loss in anticoagulant activity following injection was due to adsorption, modification, or inactivation by plasma proteins or proteases, SEL 2489 was incubated with pooled human platelet-poor plasma or whole blood for $60 \mathrm{~min}$ at $37{ }^{\circ} \mathrm{C}$ before initiating coagulation by the addition of thromboplastin and calcium. There was no evidence for loss of activity over time during incubation in plasma or whole blood. Subsequent work with a monoiodinated derivative

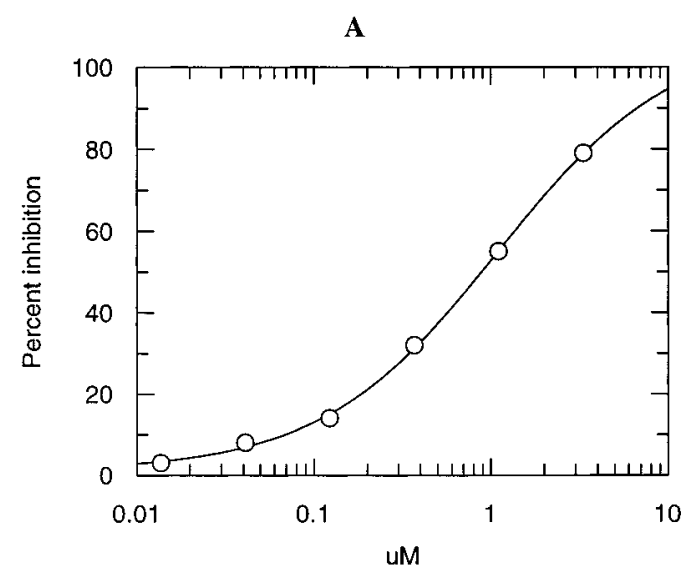

B

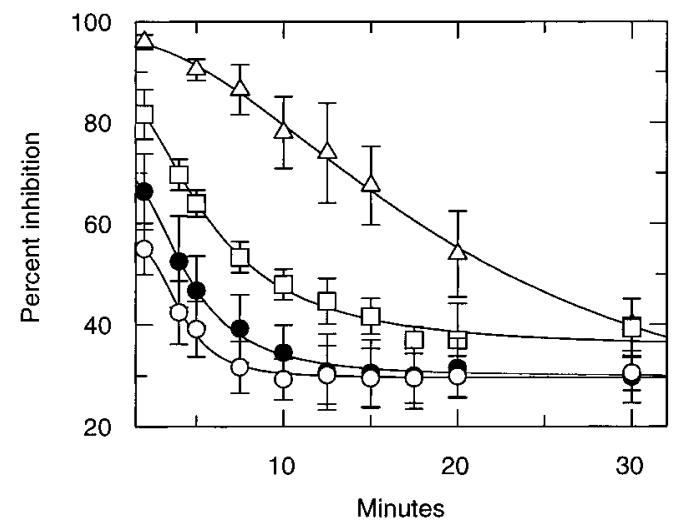

FIGURE 5: Inhibition of in vitro and ex vivo coagulation assays with SEL 2489. (A) Rabbit pooled plasma was incubated with increasing concentrations of SEL 2489 (Ac-F[pNH $\left.\left.{ }_{2}\right]-C h g-R L P\right)$ and assayed in the dilute prothrombin time in vitro coagulation assay. (B) SEL 2489 was administered as an $i v$ bolus dose to anesthetized rabbits at $0.75 \mathrm{mg} / \mathrm{kg}(\bigcirc) n=7 ; 1.25 \mathrm{mg} / \mathrm{kg}(\circlearrowleft) n=4 ; 2 \mathrm{mg} / \mathrm{kg}$ ( $\square$ ) $n=3$; and $4 \mathrm{mg} / \mathrm{kg}(\triangle) n=2$. Blood samples were withdrawn at the time indicated and assayed for inhibition of coagulation in the dilute prothrombin time assay. Means and standard errors of the means at each time point are shown.

of SEL 2489 showed that elimination in rats occurs primarily via hepatorenal clearance. ${ }^{2}$

\section{DISCUSSION}

A variety of small molecule mechanism-based inhibitors have been developed for thrombin based on the tripeptide D-Phe-Pro-Arg which mimicks thrombin's cleavage sites in fibrinogen $(24,25)$. An inherent difficulty with this class

${ }^{2}$ Schetz, J. A., Thorpe, D. S., Ostrem, J. A., Safarova, A., Stringer, S. K., LoCascio, J. C., Spoonamore, J., Kasireddy, Wildgoose, P., and Strop, P. (submitted for publication). 
of inhibitors is lack of specificity. Potent thrombin inhibitors often inhibit related plasma serine proteases important in anticoagulation and fibrinolysis such as activated protein $\mathrm{C}$, tissue plasminogen activator, and plasmin $(26,27)$. This problem is illustrated by the tripeptide Ac-Tyr-Ile-Arg which, even though a poor substrate for thrombin (Figure 3), becomes a potent inhibitor of both thrombin and trypsin by conversion to the boronic acid derivative (Figure 4). Surprisingly, although the tripeptide Tyr-Ile-Arg contains arginine which typically occupies the S1 subsite in trypsin-like serine proteases, there is no evidence that this sequence mimics a natural substrate of factor Xa. A reverse binding mode, similar to that observed for the $\mathrm{N}$-terminal residues of hirudin binding in thrombin's active site cleft $(28,29)$, may partly explain the unusual selectivity of this series of inhibitors. Furthermore, even though there is a high degree of conservation in the active site topology of factor Xa, thrombin, and other plasma serine proteases (30), the use of a competition step during library screening where factor Xa is inactivated with either of the small active site inhibitors Tenstop or PPACK was sufficient to identify factor Xaspecific inhibitors. None of the peptides which were retrieved with factor Xa from combinatorial libraries composed of several million compounds inhibited thrombin or trypsin, making it unnecessary to use competitive selection during the binding assay, as has been described for selection of factor VIIa inhibitors with reduced affinity for factor XIa, kallikrein, and plasmin (31). It is interesting to note that a related screening method, phage display, found no comparable sequence consensus in protease resistant clones when factor Xa substrates and inhibitors were selected from a library containing a randomized hexapeptide composed of all 20 L-amino acids (32).

Inhibition of enzymatic activity in assays consisting of purified human factor $\mathrm{Xa}$, chromogenic substrate, and $\mathrm{Ca}^{2+}$ free buffer indicates that the prothrombinase complex is not necessary for factor Xa inhibition by the Tyr-Ile-Arg motif. On the other hand, the ability of this family of inhibitors to inhibit factor Xa activity in the prothrombinase complex (Figure 1), as well as prolong coagulation in in vitro and $e x$ vivo assays (Figure 5) demonstrates that the presence of normal plasma constituents does not interfere with the interaction of the peptide with factor Xa's active site. Potent tri- and pentapeptides derived from the Tyr-Ile-Arg-Leu-Pro consensus sequence are orally available and efficacious in animal models of thrombosis at doses which have negligible effect on coagulation in in vitro assays. ${ }^{3}$ Development of an orally active anticoagulant with minimal bleeding side effects should provide significant benefits in the treatment and prevention of deep vein thrombosis, acute and chronic restenosis following angioplasty, endotoxin-induced disseminated intravascular coagulation, and in long-term outpatient care. Collectively, these results provide further evidence of the unique contribution of combinatorial libraries to the rapid identification of unexpected ligands without prior knowledge of the three-dimensional structure of the active site or binding pocket of a target enzyme. The availability

\footnotetext{
${ }^{3}$ Stringer, S. K., Ostrem, J. A., Al-Obeidi, F., Walser, A., Safar, P., Safarova, A., LoCascio, J. C., Spoonamore, J., Thorpe, D. S., Kasireddy, P., Ashmore, B., Strop, P., and Wildgoose, P. (submitted for publication).
}

of small, factor $\mathrm{Xa}$ specific inhibitors opens up new possibililities in regulating hemostatic mechanisms initiated by both intrinsic and extrinsic pathways of coagulation, an essential goal for progress in acute and long-term antithrombotic therapy.

\section{ACKNOWLEDGMENT}

We thank Dasha Cabel, Aleksandra Weichsel, Ron Jung, Brian Ashmore, and Luwei Zhao for support in synthesis of the peptide libraries and analogues, Charlie Chen for assistance with bioassays, and Nina Ma, Victor Nikolaev, and Farid Abdul-Latif for analytical support.

\section{REFERENCES}

1. Handin, R. I. (1991) in Harrison's Principles of Internal Medicine, 12th ed. (Wilson, J. D., Braunwald, E., Isselbacher, K. J., Petersdorf, R. G., Martin, J. B., Fauci, A. S., and Root, R. K., Eds.) pp 348-353, McGraw-Hill Inc., New York.

2. Davie, E. W., Fujikawa, K., and Kisiel, W. (1991) Biochemistry 30, 10363-10370

3. Colman, R. W., Marder V. J., Salzman, E. W., and Hirsh, J. (1994) in Hemostasis and Thrombosis (Colman, R. W., Hirsh, J., Marder, V. J., and Salzman, E. W., Eds.) pp 3-17, J. B. Lippincott Co., Philadelphia, PA.

4. Antman, E. M. (1994) Circulation 90, 1624-1630.

5. Gusto IIa investigators (1994) Circulation 90, 1631-1637.

6. Neuhaus, K.-L., Essen, R.v., Tebbe, U., Jessel, A., Heinrichs, H., Maurer, W., Doring, W., Harmjanz, D., Kotter, V., Kalhammer, E., Simon, H., and Horacek, T. (1994) Circulation $90,1638-1642$.

7. Jordan, S. L., Waxman, L., Smith, D. E., and Vlasuk, G. P. (1990) Biochemistry 29, 11095-11100.

8. Waxman, L., Smith, D. E., Arcuri, K. E., and Vlasuk, G. P. (1990) Science 248, 593-596.

9. Vlasuk, G. P., Ramjit, D., Fujita, T., Dunwiddie, C. T., Nutt, E. M., Smith, D. E., and Shebuski, R. J. (1991) Thromb Haemost. 65, 257-262.

10. Schaffer, L. W., Davidson, J. T., Vlasuk, G. P., and Siegl, P. K. S. (1991) Circulation 84, 1741-1748.

11. Lynch, J. J., Sitko, G. R., Lehman, E. D., and Vlasuk, G. P. (1995) Thromb. Haemost. 74, 640-645.

12. Gruber, A., Hanson, S. R., Kelly, A. B., Yan, B. S., Bang, N., Griffin, J. H., and Harker, L. A. (1990) Circulation 82, 578585.

13. Biemond, B. J., Levi, M., Cate, H. t., Soule, H. R., Morris, L. D., Foster, D. L., Bogowitz, C. A., Poll, T. v. d., Buller, H. R., and Cate, J. W. t. (1995) Thromb. Haemost. 73, 223230

14. Sitko, G. R., Ramjit, D. R., Stabilito, I. I., Lehman, D., Lynch, J. J., and Vlasuk, G. P. (1992) Circulation 85, 805-815.

15. Harker, L. A., Hanson, S. R., and Kelly, A. B. (1995) Thromb. Haemost. 74, 464-472.

16. Lam, K. S., Salmon, S. E., Hersh, E. M., Hruby, V. J., Kazmierski, W. M., and Knapp, R. J. (1991) Nature 354, 8284.

17. Houghten, R. A., Pinilla, C., Blondelle, S. E., Appel, J. R., Dooley, C. T., and Cuervo, J. H. (1991) Nature 354, 84-86.

18. Furka, A., Sebestyen, F., Asgedom, M., and Dibo, G. (1991) Int. J. Pept. Protein Res. 37, 487-493.

19. Bradford, M. M. (1976) Anal. Biochem 72, 248-254.

20. Kisiel, W., Kondo, S., Smith, K. J., McMullen, B. A., and Smith, L. F. (1987) J. Biol. Chem. 262, 12607-12613.

21. Chattopadhyay A., James H. L., and Fair, D. S. (1992) J. Biol. Chem. 267, 12323-12329.

22. Bajusz, S., Barabas, E., Tolnay, P., Szell, E., and Bagdy, D. (1978) Int. J. Pept. Protein Res. 12, 217-221.

23. Kettner, C., and Shaw, E. (1979) Thromb. Res. 14, 969-973.

24. Claeson, G. (1994) Blood Coag. Fibrinol. 5, 411-436. 
25. Markwardt, F., and Hauptmann, J. (1993) Adv. Exp. Med. Biol. 340, 143-171.

26. Callas, D., Bacher, P., Iqbal, O., Hoppensteadt, D., and Fareed, J. (1994) Thromb. Res. 74, 193-205.

27. Callas, D., and Fareed, J. (1995) Thromb Haemost. 74, 473481.

28. Rydel, T. J., Ravichandran, K. G., Tulinsky, A., Bode, W., Huber, R., Roitsch, C., and Fenton, J. W., II (1990) Science 249, 277-280.

29. Grutter, M. G., Priestle, J. P., Rahuel, J., Grossenbacher, H., Bode, W., Hofsteenge, J., and Stone, S. R. (1990) EMBO J. 9, 2361-2365.
30. Padmanabhan, K., Padmanabhan, K. P., Tulinsky, A., Park, C. H., Bode, W., Huber, R., Blankenship, D. T., Cardin, A. D., and Kisiel, W. (1993) J. Mol. Biol. 232, 947-966.

31. Dennis, M. S., and Lazarus, R. A. (1994) J. Biol. Chem. 269, 22137-22144.

32. Mathews, D. J., and Wells, J. A. (1993) Science 260, 11131117.

33. Kettner, C., Mersinger, L., and Knabb, R. (1990) J. Biol. Chem. $265,18289-18297$.

BI971147E 